\title{
Indeks Masa Tubuh terhadap Penyembuhan Luka Perineum Ibu Nifas
}

\author{
Nina Zuhana ${ }^{1}$, Lia Dwi Prafitri ${ }^{2}$, Wahyu Ersila ${ }^{3}$ \\ STIKES Muhammadiyah Pekajangan Pekalongan, Jl.Raya Ambokembang No.8 Kedungwuni Pekalongan \\ Email: ninazuhana@gmail.com
}

\begin{abstract}
Abstrak. Perawatan perineum yang kurang baik dapat menyebabkan timbulnya infeksi pada perineum yang dapat menghambat proses penyembuhan luka. Beberapa faktor yang mempengaruhi penyembuhan luka perineum diantaranya status nutrisi, istirahat, stress, infeksi, merokok, kondisi medis dan pengobatan dan obesitas. Obesitas atau berat badan yang berlebih dapat terjadi pada berbagai usia, menyebabkan penutupan luka kurang baik. Penelitian ini bertujuan untuk mengetahui hubungan indeks massa tubuh dengan penyembuhan luka perineum ibu nifas. Jenis penelitian yang dilakukan adalah survey analitik Populasi yang digunakan dalam penelitian ini adalah seluruh ibu nifas yang mempunyai luka jahit perineum di wilayah kabupaten Pekalongan. Dengan tehnik pengambilan sampel Accidental sampling dari tanggal 21 Maret sampai dengan 2 Mei 2017 didapatkan 30 ibu nifas. Pengumpulan data penelitian menggunakan kuesioner. Analisa data yang digunakan adalah uji korelasi pearson. Hasil penelitian menunjukkan ada hubungan antara indeks massa tubuh dengan penyembuhan luka perineum ibu nifas dengan $p$ value $0,003(<0,05)$. Diharapkan tenaga kesehatan dapat memberikan informasi kepada ibu nifas bahwa status gizi seorang wanita dapat mempengaruhi penyembuhan luka dan dalam memberikan asuhan kepada ibu nifas tidak hanya secara fisik maupun psikis tetapi secara holistic(menyeluruh) dan harus diperhatikan faktor-faktor lain seperti personal hygiene,lingkungan dan pengetahuan tentang perawatan luka jahit perineum.
\end{abstract}

Kata kunci: Indeks Massa Tubuh, Penyembuhan Luka Perineum

\section{PENDAHULUAN}

Hasil Survey Demografi dan Kesehatan Indonesia (SDKI) tahun 2012, rata-rata angka kematian ibu (AKI) tercatat mencapai 359 per 100.000 kelahiran hidup, ini berarti kesehatan ibu justru mengalami kemunduran selama 5 tahun. Pada tahun 2007, AKI di Indonesia sebenarnya telah mencapai 228 per 100.000 kelahiran hidup. Penyebab kematian ibu dikarenakan perdarahan, eklampsia, infeksi, persalinan macet, dan komplikasi keguguran (Kemenkes, 2010).

Salah satu penyebab utama kematian ibu pada ibu nifas adalah sepsis. Faktor penyebab terjadinya infeksi nifas dapat berasal dari perlukaan pada jalan lahir yang merupakan media yang baik untuk berkembangnya kuman karena daya tahan tubuh ibu setelah melahirkan yang rendah, perawatan yang kurang baik dan kebersihan yang kurang terjaga pada perlukaan jalan lahir (Prawirohardjo, 2008).

Hasil penelitian Buhling dkk melaporkan bahwa sekitar $70 \%$ wanita bersalin memerlukan perbaikan dan penjahitan perineum, namun tingginya angka tersebut tidak didukung dengan prosedur penjahitan dan monitoring penyembuhan luka yang baik (Sohail, 2009)

Perawatan perineum yang kurang baik dapat menyebabkan timbulnya infeksi pada perineum yang dapat menghambat proses penyembuhan luka. Biasanya penyembuhan luka pada robekan perineum ini akan sembuh bervariasi ada yang sembuh normal dan 
ada yang mengalami keterlambatan dalam penyembuhan (Rukiyah,

Penyembuhan luka yang mengalami keterlambatan disebabkan karena beberapa masalah diantaranya perdarahan yang disertai dengan perubahan tanda-tanda vital, infeksi seperti kulit kemerahan, demam dan timbul rasa nyeri, pecahnya luka jahitan sebagian atau seluruhnya akbiat terjadinya trauma serta menonjolnya organ bagian dalam ke arah luar akibat luka tidak segera menyatu dengan baik (Hidayat dan Musrifatul, 2014)

$\begin{array}{ccc}\text { Beberapa } & \text { faktor } & \text { yang } \\ \text { mempengaruhi } & \text { penyembuhan } & \text { luka }\end{array}$
perineum diantaranya status nutrisi, istirahat, stress, infeksi, merokok, kondisi medisdan pengobatan dan obesitas (Boyle, 2008) Obesitas atau berat badan yang berlebih dapat terjadi pada berbagai usia, menyebabkan penutupan luka kurang baik. Adanya lemak yang berlebihan akan menghalangi suplai darah yang baik sehingga luka mudah infeksi atau timbul luka baru. Suplai darah yang tidak adekuat pada daerah luka, Oksigen sangat diperlukan untuk sel, sirkulasi yang buruk akan memperlambat atau bahkan menghentikan proses penyembuhan. Oksigenasi akan terhalangi jika posisi tubuh tidak diperhatikan misal daerah bokong (Boyle, 2009). Tujuan penelitian ini untuk mengetahui hubungan indeks massa tubuh terhadap penyembuhan luka perineum ibu nifas di kabupaten Pekalongan.

\section{METODE}

Penelitian ini menggunakan metode survey analitik yang terdiri dari 1 variabel bebas dan 1 variabel terikat. variabel bebas (independent) dalam penelitian ini yaitu indeks massa tubuh, sedangkan
Variabel terikat (dependent) dalam penelitian ini adalah penyembuhan luka perineum. Variabel indeks massa tubuh yang dimaksud dalam penelitian ini adalah Hasil pengukuran dengan membandingkan antara $\mathrm{BB} / \mathrm{TB}\left(\mathrm{m}^{2}\right)$ berdasarkan WHO/FAO. Sedangkan variabel penyembuhan luka perineum adalah lama kembalinya jaringan yang rusak seperti keadaan semula, dengan menggunakan lembar observasi skala REEDA dengan hasil ukur sesuai bila luka perineum sembuh kurang dari sama dengan 8 hari, tidak sesuai bila luka perineum sembuh lebih dari 8 hari post partum. Populasi yang digunakan dalam penelitian ini adalah seluruh ibu nifas yang mempunyai luka jahit perineum di wilayah kabupaten Pekalongan. Dengan tehnik pengambilan sampel Accidental sampling dari tanggal 21 Maret sampai dengan 2 Mei 2017 didapatkan 30 nifas. Alat yang digunakan untuk variabel penyembuhan luka jahit perineum adalah ceklist dan alat kesehatan (handscoon, pinset, deppers, senter), sedangkan alat yang digunakan untuk variabel indeks massa tubuh pada penelitian ini adalah dalam bentuk kuesioner. Metode pengumpulan data pada variabel penyembuhan luka perineum adalah observasi (pengamatan) terhadap luka perineum sampai luka benar-benar sembuh, kering dan tidak ada tanda-tanda infeksi, kemudian lama penyembuhan dicatat di lembar observasi. Sedangkan hasil pengukuran langsung BB dengan menggunakan timbangan injak dan TB dengan menggunakan pengukur TB, kemudian dicatat pada lembar kuesioner. Analisa data dilakukan untuk menguji korelasi dari dua variabel dengan skala numerik sehingga menggunakan uji statistik dengan uji korelasi pearson 
dengan menggunakan level of significance $(\alpha$ : alpha) sebesar 5\% $(0,05)$.

\section{HASIL DAN PEMBAHASAN}

Hasil analisa univariat adalah sebagai berikut

Tabel 1 : Analisa indeks massa tubuh pada ibu nifas

\begin{tabular}{cccccc}
\hline $\begin{array}{c}\text { Variabe } \\
\mathbf{l}\end{array}$ & $\begin{array}{c}\text { Mea } \\
\mathbf{n}\end{array}$ & $\begin{array}{c}\text { Media } \\
\mathbf{n}\end{array}$ & $\begin{array}{c}\text { Standa } \\
\mathbf{r} \\
\text { Deviasi }\end{array}$ & Sig & $\begin{array}{c}\text { Min } \\
- \\
\text { Mak }\end{array}$ \\
\hline $\begin{array}{c}\text { Indeks } \\
\text { Massa }\end{array}$ & & & & & \\
Tubuh & 23,32 & 22,62 & 3,659 & 0,19 & $18-$ \\
\hline
\end{tabular}

Dari hasil analisa indeks massa tubuh pada ibu nifas di wilayah kerja Kabupaten Pekalongan didapatkan IMT terendah 18 dan IMT tertinggi adalah 32. Hasil uji normalitas menunjukkan angka signifikansi saphiro wilk sebesar 0,190 $(>0,05)$, berarti distribusi data normal.

Berdasarkan hasil penelitian diatasbahwa rata-rata ibu nifas memiliki status gizi yang baik yaitu 23,3 karena status gizi yang baik sangat penting untuk mempercepat proses pemulihan luka perineum dan penting untuk aktivitas, metabolisme, cadangan dalam tubuh, proses memproduksi ASI

Keluarga dan lingkungan dapat berkontribusi terhadap perubahan berat badan karena pengaruh pola makan dan gaya hidup. Faktor lain seperti faktor psikologis juga sangat penting terhadap perubahan berat badan karena dapat mempengaruhi kebiasaan makan seseorang. Sebagian orang makan lebih sedikit banyak sebagai respon terhadap keadaan psikologis yang negatif seperti marah, bosan atau sedih namun ada pula yang bereaksi sebaliknya (Ikawati Z, 2010).
Tabel 2. Analisa penyembuhan luka perineum

\begin{tabular}{lccccc}
\hline Variabel & Mean & Median & SD & Sig & $\begin{array}{c}\text { Min- } \\
\text { Mak }\end{array}$ \\
\hline $\begin{array}{l}\text { penyem } \\
\text { buhan } \\
\text { luka } \\
\text { perineu } \\
\text { m }\end{array}$ & & & & & \\
\hline
\end{tabular}

Dari hasil analisa penyembuhan luka perineum pada ibu nifas di wilayah kerja Kabupaten Pekalongan didapatkan waktu penyembuhan minimal 4 hari dan maksimal 14 hari. Hasil uji normalitas menunjukkan angka signifikansi saphiro wilk sebesar $0,01 \quad(<0,05)$, hasil transformasi data sehingga di dapatkan nilai sig 0,625 hal ini menunjukkan distribusi data normal.

Menurut Boyle (2008) bahwa luka terbuka dan dehisensi parsial atau total 610 hari setelah pembedahan biasanya berkaitan dengan infeksi. Faktor penyebab terjadinya infeksi ibu yaitu bisa berasal dari perlukaan jalan lahir yang merupakan media yang baik berkembangnya kuman. Hal ini diakibatkan oleh daya tahan tubuh ibu yang rendah setelah melahirkan, perawatan yang kurang baik dan kebersihan yang kurang terjaga (BKKBN, 2004 dalam Moloku, 2013).

Penyembuhan luka adalah proses penggantian dan perbaikan fungsi jaringan yang rusak (Boyle 2009). Apabila luka jahitan tersebut pada hari ke-10 belum sembuh dapat dikatakan proses penyembuhannya lama. Dapat disebabkan karena kurangnya perawatan ataupun kurangnya nutrisi sehingga secara umum dapat mengakibatkan berkurangnya kekuatan luka, meningkatnya dehisensi luka, 
meningkatnya kerentanan terhadap infeksi, dan parut dengan kualitas yang buruk. Defisiensi nutrien tertentu dapat berpengaruh pada penyembuhan (Boyle 2009).

Tabel 3. Analisa hubungan indeks massa tubuh dengan penyembuhan luka perineum

\begin{tabular}{cccc}
\hline \multicolumn{1}{c}{ Variabel } & Mean & $\begin{array}{c}\text { Min- } \\
\text { Mak }\end{array}$ & Sig \\
\cline { 1 - 3 } \multicolumn{1}{c}{ IMT } & 23,32 & $18-32$ & \\
\cline { 1 - 1 } $\begin{array}{l}\text { penyembuhan } \\
\text { luka } \\
\text { perineum }\end{array}$ & 8,30 & $4-14$ & 0,003 \\
\hline
\end{tabular}

Dari tabel diatas didapatkan nilai $p$ value menggunakan uji korelasi pearson didapatkan 0,003 hal ini menunjukan bahwa ada hubungan antara indeks massa tubuh dengan penyembuhan luka perineum

Hasil penelitian ini sesuai dengan fitri (2013) yaitu ibu nifas dengan status gizi normal (IMT 18,5-24,9) maka waktu penyembuhan lukanya lebih cepat daripada yang status gizinya kurang (IMT $<$ 18,5) dan lebih (> 25-29,9). Hasil penelitian Handayani (2014) juga menunjukkan bahwa ada pengaruh gizi terhadap penyembuhan luka responden yang memiliki gizi yang baik akan berdampak pula pada penyembuhan luka perineum.

Menurut Boyle (2009) Waktu penyembuhan luka dipengaruhi oleh perfusi jaringan dan oksigen, merokok, gangguan hati, stress, kondisi medis dan pengobatan, status nutrisi, infeksi, asuhan kurang optimal, obesitas, karakteristik ibu bersalin, kondisi perlukaan dan perawatannya
Status gizi adalah suatu keadaan tubuh yang diakibatkan oleh keseimbangan antara asupan zat gizi dengan kebutuhan. Keseimbangan tersebut dapat dilihat dari pertumbuhan yaitu berat badan dan tinggi badan (Supariasa, 2012). Peninjauan peran berbagai nutrient khususnya dalam mengidentifikasi pengaruh nutrisi dalam penyembuhan luka perineum yang efisien setelah melahirkan. Wanita yang baru melahirkan tidak dapat dihindari mengalami pola tidur yang kurang, nutrisi yang tidak adekuat dan stress psikologis (Hayu R, 2013)

Obesitas atau berat badan yang berlebih dapat terjadi pada berbagai usia, menyebabkan penutupan luka kurang baik. Adanya lemak yang berlebihan akan menghalangi suplai darah yang baik sehingga luka mudah infeksi atau timbul luka baru. Suplai darah yang tidak adekuat pada daerah luka, Oksigen sangat diperlukan untuk sel, sirkulasi yang buruk akan memperlambat atau bahkan menghentikan proses penyembuhan. Oksigenasi akan terhalangi jika posisi tubuh tidak diperhatikan misal daerah bokong (Boyle, 2009).

Nutrisi yang baik untuk ibu nifas tentu saja kana bermanfaat bagi ibu dan bayi. Mal nutrisi secara umum dapat mengakibatkan berkurangnya kekuatan luka, meningkatnya dehisensi luka, meningkatnya kerentanan terhadap infeksi dan parut dengan kualitas buruk (Boyle 2009). Defisiensi nutrient tertentu dapat berpengaruh pada penyembuhan contohnya defisiensi zink akan mengurangi kecepatan epitelisasi, mengurangi sintesis kolagen sehingga mengurangi kekuatan luka. Asam lemak tak jenuh yang esensial dibutuhkan dalam 
fase inflamasi dan vitamin A penting dalam deferensiasi sel dan kreatinisasi epitel. Vitamin C yang adekuat akan lebih lemah (Hayu R, 2013)

\section{KESIMPULAN}

1. indeks massa tubuh pada ibu nifas di wilayah kerja Kabupaten Pekalongan didapatkan IMT terendah 18 dan IMT tertinggi adalah 32

2. waktu penyembuhan minimal 4 hari dan maksimal 14 hari

3. terdapat hubungan antara indeks massa tubuh dengan penyembuhan luka perineum dengan $p$ value 0,003

\section{REFERENSI}

Boyle. 2009. Pemulihan Luka. Jakarta: Buku Kedokteran EGC

Kemenkes RI. 2010. Survey Demografi dan Kesehatan Indonesia (SDKI) 2007 AKI. Diakses tanggal 19 April 2016. EGC

Fitri, Elida. 2013. Faktor-Faktor Yang Mempengaruhi Lamanya Penyembuhan Lukaperineum Pada Ibu Nifas Di Rumah Sakit Umum Dr. Zainoel Abidin Banda Aceh.

Handayani Y, \& Idriana A. 2014. Faktor faktor yang mempengaruhi penyembuhan luka perineum pada ibu nifas di rumah sakit umum dr. Zainoel abiding banda aceh. Skripsi. Program studi DIV kebidanan STIKES u'budiyah Banda Aceh. http://simtakp.uui.ac.id/dockti/YULIA_ HANDAYANI-skripsi.pdf

Hayu R, Rohmawati A, \& Alie Y. 2013. Hubungan antara status nutrisi pada ibu nifas dengan penyembuhan luka perineum di wilayah kerja puskesmas cukir kabupaten jombang
Hidayat, A.A \& Musrifatul, U. 2014.Pengantar Kebutuhan Dasar Manusia.Jakarta : Salemba Medika

Ikawati, Z.2010. Resep Hidup Sehat: Menumpas Obesitas. Kanisius. Yogyakarta

Moloku, F. 2013. Hubungan pengetahuan tentang Perawatan dengan penyembuhan Luka episiotomy pada Ibu post partum di ruangan IRINA D bawah RSUP Prof. Dr. R. D. Kandau Malalayang.ejournal keperawatan (e-Kp) Volume 1 Nomor 1, Agustus 2013. Diakses tanggal $28 \quad$ Juni 2017 https://ejournal.unsrat.ac.id/index.p hp/jkp/article/viewFile/2183/1741.

Prawirohardjo, S. 2008. Buku Acuan Nasional Pelayanan Kesehatan Maternal dan Neonatal.Jakarta : Yayasan Bina Pustaka Sarwono Prawirohardjo

Rukiyah, A, Y \& Yulianti, L. 2010.Asuhan kebidanan IV (patologi kebidanan). (Cetakan Pertama). Jakarta: Trans Info Media.

Sohail S, Abbas T, Ata S. Comparison between synthetic vicryl \& chromic catgut on perineal repair. Medical Channel. 2009;15(2):48-50.

Supariasa, 2012.Penilaian Status Gizi, Jakarta. EGC 